\title{
Penerapan Metode Smart Games dalam Upaya Peningkatan Hasil Belajar Operasi Bilangan Berpangkat
}

\author{
Nanik Endarwiyani ${ }^{(1)}$ \\ ${ }^{1}$ SMP Negeri 3 Ngunut, \\ Email: ${ }^{1}$ endarwiyani.nanik@gmail.com
}

\begin{abstract}
ABSTRAK
Penelitian ini menggunakan jenis penelitian tindakan kelas (PTK). Subjek penelitian adalah siswa Kelas IX B. Dalam penelitian ini peneliti sebagai guru (pengajar), guru kelas (mitra peneliti) sebagai observer proses pembelajaran Operasi Bilangan Berpangkat. Hasil penelitian menunjukkan bahwa penerapan Metode Smart Games untuk meningkatkan Hasil belajar siswa pada materi Operasi Bilangan Berpangkat siswa Kelas IX B SMP Negeri 3 Ngunut Tulungagung mempunyai kriteria keberhasilan baik. Hal ini dibuktikan dengan adanya peningkatan Hasil belajar siswa berdasarkan nilai post test per siklus dengan nilai di atas KKM yaitu persentase pada siklus I $66,7 \%$ dan pada siklus II $87,9 \%$. Simpulan yang diperoleh dari hasil penelitian ini adalah bahwa penerapan pembelajaran Operasi Bilangan Ber $\neg$ pangkat melalui Metode Smart Games dapat meningkatkan Hasil belajar siswa Kelas IX B SMP Negeri 3 Ngunut Tulungagung dan dapat mempermu-dah siswa dalam menyelesaikan per-soalan Operasi Bilangan Berpangkat. Oleh karena itu guru menggunakan Metode Smart Games dalam pembelajaran Matematika pada materi Operasi Bilangan Berpangkat agar Hasil belajar siswa meningkat.
\end{abstract}

Kata kunci: Hasil belajar, Operasi Bilangan Berpangkat, Smart Games,

\section{PENDAHULUAN}

Pembelajaran adalah usaha guru dalam membentuk perilaku siswa sesuai tujuan yang diinginkan dengan cara menyediakan lingkungan yang mendukung agar terjadi interaksi yang baik sesama siswa. Dengan kata lain

pembelajaran diartikan sebagai suatu proses menciptakan lingkungan sebaikbaiknya agar terjadi kegiatan belajar mengajar yang berdaya guna. (Sugandi dan Haryanto 2003: 35). Pembelajaran pada hakikatnya merupakan proses komunikasi transaksion-al yang bersifat timbal balik, baik antara Guru dengan siswa, maupun antara siswa dengan siswa, untuk mencapai tujuan yang telah ditetapkan. (Susilana, 2008: 9)

Matematika merupakan ilmu universal yang mendasari perkembangan teknologi modern, mempunyai peran penting dalam berbagai disiplin dan memajukan daya piker manusia. Perkembangan pesat di bidang teknologi informasi dan komunikasi dewasa ini dilandasi oleh perkem $\neg$ bangan matematika di bidang teori bilangan, aljabar, analisis, teori Operasi Bilangan Berpangkat dan ma-tematika diskrit. Untuk menguasai dan mencipta teknologi di masa depan diperlukan penguasaan matematika yang kuat sejak dini.

Mata pelajaran Matematika perlu diberikan kepada semua peserta didik mulai dari sekolah dasar untuk membekali peserta didik dengan kemampuan berpikir logis, analitis sistematis, kritis, dan kreatif, serta kemampuan bekerjasama. Kompetensi tersebut diperlukan agar peserta didik dapat memiliki kemampuan memperoleh, mengelola, dan memanfaatkan informasi untuk bertahan hidup pada keadaan yang selalu berubah, tidak pasti, dan kompetitif.

Standar kompetensi dan kompetensi dasar matematika dalam dokumen ini disusun sebagai landasan pembelajaran untuk mengembangkan kemampuan tersebut di atas. Selain itu dimaksudkan pula untuk mengembangkan kemampuan menggunakan matematika dalam pemecahan masalah dan mengkomunikasikan ide atau gagasan dengan menggunakan simbol, tabel, diagram, dan media lain. 
Vol. 1 No. 1, Oktober 2017

Pendekatan pemecahan merupakan fokus dalam pembelajaran matematika yang mencakup masalan tertutup dengan solusi tunggal, masalah terbuka dengan solusi tidak tung $\neg$ gal, dan masalah dengan berbagai cara penyelesaian. Untuk meningkatkan kemampuan memecahkan masalah perlu dikembangkan keterampilan memahami masalah, membuat model matematika, menyelesaikan masalah, dan menafsirkan solusinya.

Dalam setiap kesempatan, pembelajaran matematika hendaknya dimulai dengan pengenalan masalah yang sesuai dengan situasi (contextual problem). Dengan mengajukan masalah kontekstual, peserta didik secara bertahap dibimbing untuk menguasai konsep matematika. Untuk meningkatkan keefektifan pembelajaran, sekolah diharapkan menggunakan teknologi informasi dan komumkasi seperti komputer, alat peraga, atau media lainnya.

Dalam proses pembelajaran di kelas sering timbul masalah yang pada umumnya dialami oleh siswa. Masalah yang dihadapi siswa bersifat unik berbeda satu sama lain. Misalnya masalah dan kesulitan ataupun rendahnya hasil belajar yang dialami siswa pada mata pelajaran Matematika bisa terjadi karena berbagai faktor diantaranya Keterbatasan kemampuari, keadaan, minat dan motivasi diri siswa itu sendiri. Situasi belajar di sekolah atau kelas dan kurangnya sarana dan prasarana. Materi pelajaran yang relevan dengan kebutuhan siswa. Metode mengajar yang kurang bisa dipahami siswa bahkan kurangnya alat peraga dan alat bantu mengajar.

Apalagi mata pelajaran Matematika menuntut kemampuan Guru untuk bisa membuat siswa mengerti dan memahami tentang materi yang diajarkan dengan tidak hanya membaca buku dan teori saja melainkan harus disertai alat peraga, contoh, praktek, latihan soal, seperti soal bercerita dan sebagainya, agar siswa memiliki pengetahuan, keterampilan dan bahkan sikap ilmiah yang berujung pada pemerolehan prestasi belajar yang maksimal.

Berdasarkan hasil pengamatan dalam proses belajar mengajar dikelas, keadaan sekolah, dan melalui peninjauan bidang akademik dan non akademik, diperoleh hasil bahwa keadaan SMP Negeri 3 Ngunut Tulungagung khususnya Kelas IX B tahun ajaran 2015/2016 dalam pelajaran Matematika belum menunjukkan hasil belajar sesuai dengan KKM yang ditetapkan terutama pada pengerjaan Operasi Bilangan Berpangkat. Padahal, ditinjau dari keadaan fisik sekolah, yaitu ruang Kelas IX B sudah baik dan sesuai sebagai tempat berlangsungnya proses belajar mengajar. Pengamatan pada proses pembelajaran oleh peneliti dapat disimpulkan bahwa pelaksanaan proses belajar mengajar lah yang belum membuat siswa aktif belajar, sehingga kemampuan siswa belum tergali dengan maksimal.

Pada ulangan harian Matematika dengan Operasi Bilangan Berpangkat, di dapat rata-rata nilai sebesar 63,6 dari 33 siswa, padahal Kriteria Ketuntasan Minimalnya $(\mathrm{KKM})$ telah ditentukan nilai sebesar 70. Dan hanya 14 siswa yang mendapat nilai di atas 70 . Hal ini berarti, hanya $42,4 \%$ dari siswa yang telah mencapai ketuntasan belajar, dan yang lainnya memiliki prestasi belajar yang rendah.

Berdasarkan hal tersebut, peneliti meminta bantuan kepada teman sejawat untuk meneliti kekurangan dari pembelajaran yang telah dilaksanakan. Dari hasil diskusi dengan teman sejawat ditemukan masalah-masalah dalam proses pembelajaran Matematika yang menyebabkan menurunkan hasil belajar adalah sebagai berikut : (1) Materi kurang dapat dikuasi siswa secara optimal. (2) Siswa belum dapat menyelesaikan soal Operasi Bilangan Berpangkat. (3) Melihat hasil ulangan harian siswa diatas, bisa dilihat jika penggunaan metode pembelajaran dalam pem-belajaran Matematika pada siswa Kelas IX B belum sesuai dan membuat siswa terlihat tidak antusias untuk belajar. (4) Pembelajaran dengan metode konvensional yaitu dengan menjelaskan materi dan siswa hanya melakukan perintah mengerjakan soal tanpa penanaman konsep pembelajaran yang kuat ternyata tidak efektif dalam proses peningkatan prestasi belajar siswa.

Setelah melihat hasil analisa di atas dan tukar pendapat dengan teman sejawat, maka untuk memperoleh hasil belajar yang optimal, tidak hanya memerlukan 
suatu latihan yang terus menerus, tetapi terlebih dahulu siswa harus mengetahui inti dari materi yang dipelajarinya. Berdasarkan konsep yang mereka temukan sendiri di dalam proses pembelajaran, tentu siswa akan lebih bersemangat, dan aktif belajar serta berusaha mencari penyelesaian masalah yang diberikan oleh Gurunya dengan menggunakan kemampuan sendiri.

Adanya semangat atau motivasi siswa dalam belajar dan konsep yang tertanam dengan baik, diharapkan siswa mampu menyelesaikan setiap tugas yang diberikan dengan prosedur yang benar, sehingga hasil belajar yang diperoleh menjadi lebih baik dari semula serta terjadi peningkatan prestasi belajar siswa.

Oleh karena itu, demi memperbaiki berbagai masalah yang ada, peneliti memerlukan suatu solusi untuk mengatasi hambatan-hambatan yang terjadi. Akhirnya diputuskan dengan menggunakan Metode Smart Games dalam pembelajaran Matematika ini. Metode Smart Games adalah Metode bermain adalah cara atau pendekatan dengan bermain dalam belajar untuk mencapai tujuan yang diharapkan.

Permainan bisa dijadikan sebagai salah satu strategi pembelajaran, karena permainan memegang peranan penting bagi perkembangan anak. Pembelajaran berpusat pada siswa, sehingga siswa diharapkan lebih aktif, antusias, dan berani dalam mencari penyelesaian permasalahan yang dihadapinya, serta memungkinkan siswa menemukan sendiri informasi-informasi yang tadi perlukan untuk mencapai tujuan belajarnya, sehingga prestasi belajar siswa pun dapat meningkat.

\section{METODE}

Lokasi yang digunakan tempat penelitian adalah ruang Kelas IX B SMP Negeri 3 Ngunut Tulungagung Tahun Pelajaran 2015/2016. Alasan peneliti melaksanakan penelitian di tempat ter-sebut adalah peneliti merupakan salah satu Guru mata pelajaran tersebut sehingga memudahkan peneliti dalam melaksanakan penelitian serta dapat menghemat waktu dan biaya.

Penelitian dilaksanakan pada se-mester 2, pada tanggal 10 Februari 2016 sampai dengan 17 Februari 2016 Waktu pelaksanaan siklus pembelajaran (1) Siklus pertama Rabu, 10 Februari 2016, waktu yang diperlukan 2 x 40 menit. (2) Siklus kedua Rabu, 17 Februari 2016, waktu yang dipnlukan 2 x 40 menit.

Dalam penelitian ini subjek yang digunakan adalah seluruh siswa Kelas IX B SMP Negeri 3 Ngunut Tulungagung tahun pelajaran 2015/2016 sehanyak 33 siswa yang terdiri dari 15 siswa putra dan 18 siswa putri. Nama-narna siswa akan tersaji dalam lampiran.

Observer terdiri atas dua orang Guru yaitu, Ibu Nanik Endarwiyani, S. yang membantu peneliti dalam merekam proses pembelajaran dengan instrument yang dipilih.

Berdasarkan variable yang diteliti dan tujuan yang hendak dicapai, maka metode penelitian yang digunakan adalah dengan sistem spiral. Stephen Kemmis dan Robin Mc Taggart tahun 1988 mengembangkan model Kurt Lewin dalam suatu sistem spiral dengan empat komponen utama, yakni perencanaan (planning), tindakan (acting), observasi (observing) dan refleksi (reflecting). Namun yang membedakan dengari Kurt Lewin adalah sesudah suatu siklus selesai, yakni sesudah refleksi kemudian diikuti dengan adanya perencanaan ulang yang dilaksanakan dalam bentuk siklus tersendiri, demikian seterusnya dengan beberapa kali siklus. Dengan teknik yang digunakan peneliti ini, peneliti berupa-ya untuk meningkatkan Prestasi Belajar Maternatika siswa Kelas IX B SMP Negeri 3 Ngunut Tulungagung dengan menggunakan metode Smart Games.

Instrumen penelitian adalah alat atau sarana yang digunakan oleh peneliti untuk mengumpulkan data penelitian. Data penelitian yang dimaksud adalah sebuah informasi dari Penelitian tindakan kelas ini, yaitu berupa kata-kata, angka-angka, gambar, segala sesuatu yang dapat digunakan untuk menjawab masalah penelitian.

Instrumen yang dikembangkan oleh Guru sebagai peneliti disesuaikan berdasarkan kebutuhan data penelitian itu sendiri. Guru atau peneliti mengidentifikasi 
dan mempersiapkan berbagai ragam instrument yang diperlukan dalam penelitian tindakan kelas ini. Guru ataupun peneliti mempersiapkan instrument penelitian dengan tepat, tentunya supaya data yang terkumpul dapat lebih bermakna dan bermanfaat bagi kegiatan penelitian.

Adapun ragam instrument penelitian tindakan kelas yang telah dipersiapkan yaitu, Rencana Pelaksaaan Pembelajaran sebagai instrument rencana pelaksanaan tinda $\neg$ kan. Lembar observasi Guru sebagai instrument utama pengumpul data proses dan lembar observasi siswa, wawancara, angket dan catatan lapangan sebagai instrument pendukung pengumpul data proses.

Selain itu juga terdapat instru $\neg$ ment pengumpul data hasil, yang dapat dikumpulkan dari hasil belajar berdasarkan soal-soal yang diberikan, serta ketrampilan siswa berdasarkan rubrik yang ada.

Teknik analisis yang digunakan yaitu deskriptif persentase. Data hasil penelitian yang dianalisis meliputi ra-ta-rata kelas, ketuntasan belajar individu dan ketuntasan belajar secara klasikal. Selanjutnya hasil analisis da $\neg$ ta diperoleh baik secara kualitatif (dengan kata-kata) dan kuantitatif (dengan grafik). Hasil ini diinterprestasikan dan disimpulkan untuk menjawab permasalahan yang ada.

Analisis data dari sumber-sumber informasi hasil penelitian di dapat dari: Data hasil observasi keterlaksanaan pembelajaran melalui Metode Smart Games dan observasi aktivitas siswa dianalisis secara deskriptif untuk memberikan gambaran pelaksanaan pembelajaran dengan menggunakan Metode Smart Games. Hasil wawancara dengan siswa dianalisi secara deskriptif dengan lembar angket untuk mengetahui pendapat Guru dan siswa terhadap pernbelaiaran. Berdasarkan hasil tes siswa tiap soal diberi skor kemudian diperoleh nilai untuk setiap siswa. Data yang terkumpul dianalis dengan statistik deskriptif.

\section{HASIL}

Berdasarkan hasil pelaksanaan pada siklus I, II dapat dinyatakan bahwa terjadi peningkatan kualitas pembelajaran yang tampak dan perolehan hasil evaluasi dan keaktifan siswa.

Dari tabel 4.2 dan gambar 4.2 siklus I hasil observasi menunjukkan, prosentase keberhasilan kelengkapan menyiapkan alat dan bahan percobaan $45 \%$, prosentase keruntutan langkah-langkah yang ditempuh dalam pelaksanaan percobaan $45 \%$, prosentase keaktifan siswa dalam melaksanakan kegiatan percobaan $65 \%$, prosentase keaktifan siswa dalam mengutarakan pendapat saat berdiskusi $45 \%$ dan prosentase hasil penarikan kesimpulan akhir sesuai percobaan $50 \%$.

Berdasarkan tabel 4.5 dan gambar 4.5 siklus II hasil observasi menunjukan, prosentase keberhasilan metode kelengkapan menyiapkan alat dan bahan percobaan siswa yang disiapkan 35\%, prosentase keruntutan langkah-langkah yang ditempuh dalam pelaksanaan percobaan $85 \%$, prosentase keaktifan siswa dalam pelaksanakan kegiatan percobaan $55 \%$, prosentase keaktifan siswa dalam mengutarakan pendapat saat berdiskusi $88 \%$ dan prosentase hasil penarikan kesimpulan akhir sesuai percobaan $88,3 \%$.

Dari daftar nilai (lihat lampiran) lapat kita lihat adanya prosentase kenaikan nilai Matematika mulai dari kondisi awal pra tindakan, diketahui baru 14 siswa atau $42,4 \%$ yang mengalami ketuntasan belajar dan mendapatkan nilai sesuai dengan KKM. Hasil evaluasi siklus I menunjukkan baru 22 siswa atau 66,7\% yang mengalami ketuntasan belajar dan mendapat nilai sama dengan atau di atas KKM yaitu 70. Hal itu menunjukkan bahwa pelaksanaan siklus I belum mencapai keberhasilan, karena indika $\neg$ tor, pencapaian adalah sebesar $85 \%$ atau lebih. Siklus II menunjukkan ada 29 siswa atau $87,9 \%$ dari 33 siswa yang mengalami ketuntasan belajar Sehingga peneliti menyimpulkan bah $\neg$ wa pada siklus II ini peneliti telah mencapai keberhasilan dari penelitian tindakan kelas yang telah dilakukan.

Ketika peneliti melaksanakan siklus I, peneliti mengalami berbagai kendala antara lain beberapa siswa masih tampak bingung dalam melaksanakan kegiatan 
pembelajaran. Masih ada kelompok yang bingung dalam mengikuti langkah-langkah yang tertera dalam lembar kegiatan. Masih ada beberapa siswa yang belum aktif dalam pelaksanaan percobaan. Ketika pelaksanaan diskusi, ada beberapa siswa yang tidak aktif menyampaikan pendapatnya. Dalam menyimpulkan hasil percobaan, terdapat 2 (dua) kelompok yang malu untuk presentasi, dan hanya terdapat 3 (tiga) siswa yang mengajukan pertanyaan.

Peneliti kemudian melaksanakan siklus II sebagai perbaikan siklus I, sebelum pelaksanaan siklus II ini peneliti mengganti rencana pembelajaran Metode Smart Games baru yaitu dengan mendiskusikan materi penjumlahan, pengurangan, perkalian, pembagian dan perpangkatan pada suatu bilangan berpangkat bilangan bulat dan bentuk akar. Dalam pelaksanaan percobaan, peneliti senantiasa memberi bimbingan untuk siswanya dalam melaksanakan langkah-langkah sesuai lembar kegiatan. Peneliti pun memberi bimb-ingan siswa saat berdiskusi untuk menarik kesimpulan. Dengan adanya motivasi guru berupa reward, siswa telah terlihat aktif dalam kegiatan pembelajaran dalam melaksanakan perco $\neg$ baan, presentasi di depan kelas dan berdiskusi menarik kesimpulan. Meskipun ada kendala yaitu beberapa siswa masih belum dapat memahami persoalan yang diberikan, namun dengan hasil prestasi belajar yang dicapai dapat disimpulkan bahwa penelitian tindakan kelas dari siklus II ini telah berhasil.

\section{PEMBAHASAN}

Berdasarkan hasil penelitian tindakan kelas yang telah dilaksanakan dalam 2 siklus dengan menerapkan Metode Smart Games dalam pembelajaran Matematika pada siswa Kelas IX B SMP Negeri 3 Ngunut Tulungagung, dapat dibuat kesimpulan sebagai berikut : Penerapan Metode Smart Games dapat meningkatkan prestasi belajar Matematika siswa Kelas IX B SMP Negeri 3 Ngunut Tulungagung.

Hal ini dilihat dari prosentase kenaikan nilai Matematika siswa Kelas IX B dari pra siklus, siklus I sampai Siklus II. Pada pra siklus, siswa yang mendapat nilai minimal 70 ada 14 siswa atau 42,4\%, pada siklus I siswa yang mendapat nilai minimal 70 ada 22 siswa atau $66,7 \%$, pada siklus II siswa yang mendapat nilai minimal 70 ada 29 siswa atau $87,9 \%$ dari 33 siswa. Dari pra siklus kemudian dilaksanakan siklus I prestasi siswa mengalami prosentase kenaikan $24,2 \%$ Dan dari siklus I kemudian dilaksanakan siklus II prestasi siswa mengalami prosentase kenaikan $21,2 \%$.

Penerapan pembelajaran dan prosedur dalam penelitian ini didasarkan pada pembelajaran dengan menerapkan Metode Smart Games dalam pelaksanaan proses pembelajaran Matematika. Model yang dipakai dalam penelitian tindakan kelas ini adalah model siklus, adapun prosedur penelitiannya terdiri dari 2 siklus. Siklus I dilaksanakan pada hari Rabu tanggal 10 Februari 2016, Kompetensi Dasar 5.2.Melakukan operasi aljabar yang melibatkan bilangan berpangkat bulat dan bentuk akar, siklus II dilaksanakan hari Rabu tanggal 17 Februari 2016.

Dalam setiap pelaksanaan siklus terdiri dari 4 (empat) tahapan, yaitu perencanaan tindakan, pelaksanaan, observasi, dan refleksi, kegiatan ini dilaksanakan berdaur ulang.

Sebelum melaksanakan tindakan dalam tahap siklus, perlu perencanaan. Perencanaan ini memperhatikan setiap perubahan yang dicapai pada siklus sebelumnya terutama pada setiap tindakan yang dapat meningkatkan hasil belajar siswa. Hal ini didasarkan pada analisis perkembangan dari pra siklus, siklus I sampai siklus II.

Berdasarkan kriteria temuan dan pembahasan hasil penelitian seperti yang diuraikan pada bab IV, maka penelitian ini dapat digunakan peneliti untuk membantu guru dalam menghadapi permasalahan yang sejenis. Disamping itu, perlu penelitian lanjut tentang upaya guru untuk mempertahankan atau menjaga dan meningkatkan hasil belajar siswa.

Pembelajaran dengan menggunakan Metode Smart Games pada hakikatnya dapat digunakan dan dikembangkan oleh guru yang menghadapi permasalahan yang 
sejenis, terutama untuk mengatasi masalah peningkatan prestasi hasil belajar siswa, yang pada umumnya dimiliki oleh sebagian besar siswa.

\section{KESIMPULAN}

Berdasarkan hasil observasi dan pelaksanaan siklus I dan II juga dapat kita amati adanya perubahan kenaikan prosentase dalam menyiapkan alat dan bahan, keruntutan langkah-langkah siswa dalam melaksanakan percobaan, keaktifan siswa dalam melaksanakan kegiatan percobaan, keaktifan siswa ketika berdiskusi dan hasil akhir atau simpulan yang diperoleh dari hasil kegiatan diskusi.

\section{SARAN}

Dalam melaksanakan kegitan pembelajaran, guru hendaknya tetap melakukan perencanaan dan penataan alokasi waktu dengan baik.

\section{DAFTAR RUJUKAN}

Depdikbud. 2006. Kurikulum Tingkat Satuan Pendidikan (KTSP-SD/MI), Departemen Pendidikan Nasional.

Depdiknas, 2008. Pedoman Penyusunan KTSP SD/MI. Jakarta: BSNP

Development of an Addendum to the National Science Education Standards on

Scientific Inquiry. Center for Science, Mathematics, and Engineering Ed. USA Dimiyati dan Mudjiono. 2002. Belajar dan Pembelajaran. Jakarta: Rineka Cipta Dimyati \& Mudjiono, 2006. Belajar dan Pembelajaran. Jakarta: Rineka Cipta. Djamarah, Syaiful Bahri. 2002. Psikologi Belajar. Jakarta : PT. Rineka Cipta Fudyartanto, Ki RBS. 2002. Psikologi Pendidikan dengan Pendekatan Baru. Yogyakarta: Global Pustaka IImu.

Hayinah. 1992. Masalah Belajar, Malang: IKIP Negri Malang.

Hudoyo, H. 1988. Strategi Belajar Mengajar Matematika. Jakarta : DepDikbud. Marsigit. 2003. Revitalisasi Pendidikan Matematika. FMIPA IKIP Yogyakarta. Rahman, Hibana S. 2003. Bimbingan dan Konseling Pola 17. Yogyakarta: UCY Press Schmidth, M.K. dkk. 2009. Teori Pembelajaran dan Pengajaran. Yooyakarta: Mirza Media

Semiawan, Conny. 2002. Pendidikan Keluarga dalam Era Global. Jakarta. Prehallindo. Slavin, R. E. 1994. Educational Psychology Theory Into Practices. 4th ed. Buston: Allv and Bacon Publishers. 